\title{
The Black (and White) Humour of Artür Harfaux
}

\author{
Danièle Méaux
}

The work of Artür Harfaux, a member of Le Grand Jeu between 1927 and 1932, deserves to be reassessed. Harfaux produced a number of more or less staged photographic portraits of his friends Roger-Gilbert Lecomte, René Daumal, Josef Šíma, Maurice Henry and other protagonists of the movement. He created fancy and inventive photomontages, double exposed portraits and almost abstract pictures of veils blowing in the wind. Beyond their diversity, Harfaux's works are characterised by a subtle humour. Sometimes the humour that prevails is ironic or self-derisive, while on other occasions the works are informed by black humour or the burlesque. A study of the work of Harfaux leads to a reconsideration of the importance of humour and laughter formidable forces of destabilisation and of detachment - in the revolt of the members of Le Grand Jeu as well as in the endeavours of the Surrealists.

Keywords: Josef Šíma (1891-1971), André Breton (1896-1966), Arthur (Artür) Harfaux (1906-1995), Roger Gilbert-Lecomte (1907-1943), Roger Vailland (19071965), Maurice Henry (1907-1984), René Daumal (1908-1944), Le Grand Jeu, Surrealism, black humour, burlesque, theatricality

Artür Harfaux, the photographer and designer, took part in Le Grand Jeu collective, which developed on the fringes of the Surrealist movement between 1927 and 1932. ${ }^{1}$ Many of his photographs feature members of the group or reflect their activities. Nevertheless, his images differ from the dream-like paintings of Josef Šíma and the grave and mystical tonalities of the texts of Roger Gilbert-Lecomte who has often been considered the emblematic figure of the movement. Harfaux represents his companions with a subtle irony. Some of his unusual and caustic photomontages allude to black humour; others exploit the vein of the burlesque. In this essay we will see that humour, in various forms, constitutes an essential feature of his photographic work. This will lead us to reassess the significance of laughter in the revolt 
expressed by the members of Le Grand Jeu, and to stress its role in the activities of the Surrealists.

Le Grand Jeu movement began with the 'Simplistes' group, formed between 1922 and 1926, by four high school students from Reims - Roger Gilbert-Lecomte, René Daumal, Roger Vailland and Robert Meyrat - who combined rebellion and metaphysical aspiration, schoolboy humour and the search for 'visionary' and unknown horizons. The term 'simplisme' implies the desire to recover the intuitive knowledge capacities of childhood. In 1927, the four colleagues newly arrived in Paris, met Harfaux and his friend Maurice Henry, both of whom were from Cambrai. Others joined them, such as the Czech painter Šima. Appalled by the absurdity of society and eager for absolutes, the members of Le Grand Jeu aimed to regenerate mental faculties in order to attain a form of immediate knowledge and total participation. A review entitled Le Grand Jeu was created and three editions were produced, combining drawings, photographs and texts. The fourth edition, planned for 1932, did not get beyond the draft stage. ${ }^{2}$

At the time there were many groups linked to the Surrealist movement; the relations between the members of Le Grand Jeu and the circle of André Breton were complex, consisting of unquestioned affinities, divergences and personal conflicts, with each group experiencing its own evolution and internal unrest. ${ }^{3}$ However, the members of Le Grand Jeu showed themselves to be more radical than other groups in their efforts to explore states of consciousness through experimental metaphysics. The attainment of truth required choices that permitted no concession (for Daumal, this would be asceticism, and for Gilbert-Lecomte, self-destruction through drugs). They also demonstrated a powerful attraction towards 'the Orient', suggestive of a European commitment to decadence (adopting positions close to those of Antonin Artaud, which Breton had banned in 1926). There were nevertheless disagreements within the group itself. Certain members, under the influence of mysticism, refused to be politically active, while others were in favour of more militant actions. These dissensions led to the dissolution of Le Grand Jeu in 1932, after which Harfaux drew even closer to the Surrealists.

\section{A 'Mythology' Tinged with Irony}

Histories of art and literature have tended to neglect Le Grand Jeu. Even in French-language scholarship, the movement remains shrouded in a certain mystery, and the images that survive appear as precious clues that have contributed to the constitution of a form of collective 
mythology. If others produced photographs of its members, Harfaux is responsible for the greater part of the portraits that are extant today. ${ }^{4}$ Harfaux photographed Šíma in his studio, and sketched the portraits of Vailland, Gilbert-Lecomte and Daumal. ${ }^{5}$ These images have enabled real-life characters, posing before the lens, to pass into posterity.

Certain images by Harfaux possess, however, a tonality which is more bizarre or satirical, but which nonetheless contributes to the construction of a mythology. Hommage au Marquis de Sade, for example, portrays a parody of an assassination attempt on Daumal by Gilbert-Lecomte (figure 1). ${ }^{6}$ On the right, the author of Le Mont analogue (1952), dressed in white, rolls his eyes in desperation, the pale oval shape of his face contrasted against the dark background. The aggressor, dressed in black, springs up on the left; all that emerges from the shadows are his face, his murderous hands, and a sharp blade pressed theatrically to the neck of his friend. The viewer, following the movement of the gesture, encounters a mirror on the right of the image against which the victim is being driven. This partition, which encloses the pictorial space, becomes a symbolic partner-in-crime of the assassin. The paleness of the faces and the hands is such that, emerging from the shadows, the two figures are reduced to a platitude of a foreground. The image recalls certain playthings for children, where cardboard characters have mechanical levers that enable simultaneous changes to be made to a scene; pulling a lever draws the two protagonists together, with the aggressor plunging the blade into the throat of the victim.

While the scene seems overplayed and artificial, it resembles a burlesque pantomime, in the vein of the compositions by Paul Nougé from the series Subversion des images (19291930). The Surrealists were attracted by bizarre theatricality, capable of discrediting categories of the true and the false, whether on the stage or in tableaux vivants photography. Playing with death was particularly fascinating for the members of Le Grand Jeu. In Reims, the 'Phrères Simplistes' repeated exercises that enabled them to approach the mystery of nothingness; a 'pacte d'Absolu' gave them the right of life and death over their colleagues; each member of the group had a nickname, and Gilbert-Lecomte was compared to a black angel who was able to change into a vampire with blood dripping from his mouth. ${ }^{7}$ Much later, in 1927, Daumal wrote to his friend: 'If you wanted to slit my throat [...], I would be allowed not to resist'. ${ }^{8}$ In the double portrait Hommage au Marquis de Sade, Harfaux refers ironically to the complicated impulses of this very unusual relationship.

Harfaux also produced several self-portraits characterised by impassive expressions. One of these self-portraits shows him looking sceptical, at the end of a corridor, where the closed doors appear to him as so many unsolved enigmas. Another self-portrait depicts him 
deep in thought before a complicated machine, made up of cogs, chains and metal beams, bearing the inscription 'Danger de mort'. These images, tinged with self-derision, theatricalise the same inquisitive and distanced attitude. Their strangeness recalls certain photographic self-portraits by René Magritte. ${ }^{9}$

The work Moi et moi, Dédoublement combines a translucent image of Harfaux standing with raised arms, with another darker image of him sitting cross-legged (figure 2). The image hovering above seems to emanate from its casing below, as if the model had succeeded, after a long period of concentration, to escape from the prison of his mortal coil, like Aladdin from his lamp. While Daumal worked assiduously on exercises to attain the separation of consciousness, ${ }^{10}$ and Gilbert-Lecomte went through drug induced hallucinatory experiences, the phenomenon presented here makes us rather want to smile. The special effect is manifest and there is a marked contrast between the concrete manipulations required for the double exposure (which the spectator imagines), and the search relating to the domain of spirituality, in such a way that a wholly serious approach to the phenomenon seems no longer possible. The visual and literal transposition of a mental process lends itself to irony. Should we detect here an indication of the critical distance of the photographer? Harfaux enjoyed a close association with his companions in Le Grand Jeu and a profound friendship with Daumal, ${ }^{11}$ but he nonetheless showed himself to be reserved and reluctant to be enrolled in a movement. In 1973, Henry wrote of his friend Harfaux: 'Le Grand Jeu was what really left its mark on him. But he is still astonished at having been led into this movement, to which he declares that he had never totally adhered'. ${ }^{12}$ Harfaux's early entry into the professional world, with the art publisher Braun, perhaps also helped him to avoid exhausting himself with the quest of Le Grand Jeu. ${ }^{13}$

The members of the group aspired to break down the limits of individual consciousness in order to merge into a community of initiation. ${ }^{14}$ According to GilbertLecomte's preface to the first issue of Le Grand Jeu, 'we walk united all together, each of us carrying his own corpse on his back. [...] We do not form a literary group, but a union of men bound by the same quest'. ${ }^{15}$ Harfaux tried many times to transpose this desire for union into visual form. One undated work superimposes the diaphanous portraits of the four 'Phères simplistes' to create a kind of collective ectoplasm. A collage, produced around 1928, brings together the faces of Vailland, Daumal and Gilbert-Lecomte joined by a common neck to form a three-headed being (figure 3). The visage of Daumal is frontal, while the profiles of his two colleagues face to the left and to the right. Vailland's head is intensified by a grey area which appears to be a cast shadow; the chimera thus acquires a sculptural volume which 
might resemble a medieval marquee. This trinity refers, in a parodic manner, to the threeheaded management structure of the review between 1927 and 1932.

The 'primacy of the collective over the individual' was proclaimed strongly by the members of Le Grand Jeu. ${ }^{16}$ It was also affirmed at the same time by the Surrealists, who were anxious to present a unified voice and rejected 'the supremacy of egocentric creation' ${ }^{17}$ Many were the collective representations of the actors of the movement, playing with the codes of group portraits and celebrating their communal quest. Sometimes there were playful stagings, where the very gesture of posing together had its importance; other times there were collages, such as Man Ray's L'échiquier surréaliste (1934), or Je ne vois pas la femme cachée dans la forêt, which combined an oil painting by Magritte and sixteen photo-booth images of the Surrealists. ${ }^{18}$ Irony combines again here with a desire to create a form of collective mythology.

\section{The Pataphysical Heritage}

Harfaux did not restrict himself to portraits. Between 1927 and 1930, he produced a good number of photomontages and, in 1931-32, he developed the Aléatoires series consisting of quasi-abstract images, floating and liquescent, evoking the folds of fabric and the interlacing of voile. The photographer, however, did not seek to make his work well known. He contributed to three journals (Le Grand Jeu, Phases and Le Surréalisme au service de la révolution) and participated in exhibitions of Le Grand Jeu (in particular, at the Bonaparte bookstore in June 1929), ${ }^{19}$ but a large part of his work was neither published nor exhibited until in recent years. ${ }^{20}$

The photomontages of the series Scènes de la vie courante (1929) associate heterogeneous elements, often cut from postcards, in unusual compositions. One of these works depicts a respectable looking old man who bears a remarkable resemblance to Victor Hugo (figure 4). Moving through a dark crypt, this figure seems to stumble across the naked and headless body of a beautiful young woman. This bizarre scene reflects the review members' attraction to the dream world. ${ }^{21}$ In this montage, as in the drawing entitled $\mathrm{La}$ vieille plaisanterie, ${ }^{22}$ Harfaux uses an underground space as a metaphor for the depths of the unconscious. In a similar fashion to the Surrealists, the members of Le Grand Jeu sought to subvert daily logic by resorting to the imagination. The intrusion of fantasies into 'daily life' is ironically suggested by the title of the series. 
Scènes de la vie courante demonstrate a willingness to escape from the empire of reason, which Henry referred to as 'that spectre of colleges'. ${ }^{23}$ With their incongruous arrangements, the scenes break from the normal cohesion of appearances in favour of disorder. These unusual montages resist ready comprehension yet provoke the viewer's engagement by adopting the combinatory logic of language and mimicking the mechanisms of sensory production. ${ }^{24}$ Some drawings by Harfaux juxtapose, in a similar manner, elements whose semantic cohesion escapes us; they participate in the same appeal to incongruity and nonsense. ${ }^{25}$

Harfaux produced photomontages with a great emphasis on black humour. One of these features a tubby monk getting ready to devour a dead Christ on his plate (figure 5). The violence of the Eucharist is here transposed in a literal manner. This genre of composition echoes the humorous drawings of Henry, which are characterised by a vigorous stylised line, strong anticlericalism, and a taste for nonsense and the macabre. The members of Le Grand $\mathrm{Jeu}$ had spent their childhood in the violence of the war. Dealing with death remained one of their obsessions, which black humour perhaps made easier to bear. Henry exploited, in particular, the themes of devouring and of cannibalism. An unpublished drawing from the middle of the 1930s, reminiscent of Harfaux's earlier photomontage of the monk, depicts a greedy ogre who, on discovering on his plate a newborn baby, angrily exclaims 'not baby with spinach again!' ${ }^{26}$ In Breton's Anthologie de l'humour noir (1939), cannibalism figures prominently through selected texts by Jonathan Swift, the Marquis de Sade and CharlesMarie-Georges Huysmans. ${ }^{27}$ Before this publication, the expression 'black humour' had no real meaning. The anthology proposes to the reader a particular type of humour, which exaggerates the cruelty of the world and functions as an antidote to pathos. Many of Henry's drawings operate in the same vein, as do certain works of Harfaux, such as this photomontage of the monk before his meal.

Harfaux's and Henry's tendency toward the absurd, toward incongruity or black humour, is indicative of their desire to break from the established order. This was in keeping with the aspirations of the other members of Le Grand Jeu, which bound them together in the same existential quest. The young men's correspondence is full of plays on words, comical drawings and schoolboy jokes. Some of Gilbert-Lecomte's texts are in a rather more grotesque vein; jokes, puns and incongruous turns of phrase combine in an expression of despair. ${ }^{28}$ The grotesque dimension serves as the counterpoint to the literary search for the absolute. Daumal, in particular, demonstrated a willingness to combine metaphysics with 
pataphysics. In his view, the destabilising laugh revealed the absurdity of daily existence, its chaotic and illusory dimension:

I maintain, and I know, that pataphysics is not a simple joke. And if laughing often shakes the limbs of us other pataphysicians, it is the terrible laugh in the face of the evidence that each thing is precisely [...] what it is, and not otherwise, that I am, without being everything, that it is grotesque and that any defined existence is a scandal. ${ }^{29}$

And he added, 'the pataphysical laugh is the vivid consciousness of an absurd duality, and which is an obvious fact; [...] it is the only human expression of the identity of opposites'.30 Laughter contrasts thus with rigid thought and western reasoning. A destructive factor, humour supports the aspiration of the members of Le Grand Jeu for another form of selfknowledge.

\section{Burlesque and Photography}

In 1941, Harfaux and Henry founded the 'Gagmen associés'. Henry had harboured the desire to write gags for the cinema for several years. Initially planned with Robert Tréno and Roger Salardenne, journalists with the satirical newspaper Le Canard Enchaîné, the project was aborted with the departure of the two journalists for the French 'free zone' under the administration of the Vichy government. Although delayed, Harfaux and Henry nonetheless realised the project after the war.

The two friends liked the films of the Prévert Brothers. They were, however, generally critical of French film production at the time and preferred the American model. In particular, Harfaux and Henry enjoyed the crazy humour of the Marx Brothers. They considered this form of slapstick capable of revitalising comic cinema in France. Maurice Baquet, who was also a musician and a gifted acrobat, worked with them on four of their films: Les Aventures des Pieds Nickelés (1947), Les Souvenirs ne sont pas à vendre (1948), Rondo sur la piste (1949), and Bibi Fricotin (1950). ${ }^{31}$ In a series of screenplays, Henry and Harfaux contributed to creating the outlines of a form of French burlesque, which reconciled nonsense and incoherent innovations with a narrative of poetic realism. Certain scenes pay homage to the burlesque, which had developed as a popular form in the USA. The three characters from Les Pieds Nickelés - Ribouldingue, the mischievous one; Filochard, the oddball; and Croquignol, 
the excited one - recall the comic trio of the Marx Brothers. A tension exists, as in the US slapstick comedies, between the demands of the story and the pleasure of the gags, even to the extent of compromising the coherency of the narrative. Henry was the driving force behind this enterprise, but the role played by Harfaux was far from insignificant. ${ }^{32}$ As Henry later acknowledged, 'Arthur's inventions are crazy, delirious, fragments of dreams that I carefully screen with my filmmaking knowledge to convert them into workable realities' ${ }^{33}$

While the work undertaken by the two friends can be related to the concerns of Henry, it was not so far removed from the work of the photographer, where a burlesque-like tonality was clearly perceptible. A set of photomontages, produced between 1927 and 1930, represent fragments of bodies, heads, busts or truncated limbs (figures $6,7,8) .{ }^{34}$ Here we find a headless trunk, impaled on a coat stand, lifting its arms to the sky in a strange supplication; elsewhere two plump legs, wearing court shoes, wiggle from behind the gap in a curtain; and a decapitated body stands upside down in such a way that the arms and the breasts are transformed, respectively, into strange legs and buttocks. These fragments, surprisingly credible and flesh-like, seem to move about, like a lizard's tail detached from the animal's body or a decapitated praying mantis (as described by Roger Caillois in Minotaure). ${ }^{35}$ There is something obscene about these bodyparts, which seem to move as if whole. They relate to a modernist notion of primitive life, deprived of a rudder of reason and reacting entirely by reflex. Many of Harfaux's drawings, representing incomplete ectoplasms, produce a transcription of the same imaginary themes. ${ }^{36}$

Photographers close to Surrealism, such as Man Ray, Brassaï (Gyula Halász), Jacques-André Boiffard, Raoul Ubac, Pierre Boucher and Dora Maar, were inclined to represent the human body in fragmentary, shapeless, or animal-like form. ${ }^{37}$ Fragments dominate, furthermore, with the dolls produced by Hans Bellmer; the limbs assembled in monstrous patterns seem to refuse to blend into a coherent whole, each claiming its own independence. The representation of body parts was a recurrent theme amongst those close to Le Grand Jeu. The works of Šíma depict female busts freed from arms and heads floating in evanescent landscapes. The drawings of Henry and of Mayo also feature dream-like worlds and fragmented organisms. ${ }^{38}$

What is remarkable with Harfaux is the strange drollness of the organic parts that are presented - parts that move, isolated and gauche in uncertain space. If the incomplete nature of the bodies suggests that they have been victims of some form of violence, the fragments seem to play out their own robot-like existence. The surrounding objects compete in the frame with these partially incarnated beings. Yet, the solitude of a subject submitting to 
adversity, the proximity of the body and the machine, and the importance of objects all represent characteristic traits of burlesque. ${ }^{39}$ The implication of the human sections in action endows the images with a narrative potential which can be compared to that of cinema. The slapstick comedies were often conceived through improvisation, in such a way that the 'makeshift' aspect of the photomontages accentuates their connections with burlesque. Along with the Surrealists, the members of Le Grand Jeu were familiar with and appreciated these popular films. ${ }^{40}$ The impassive face looking straight ahead that Harfaux assumes in most of his self-portraits reminds us of the imperturbable expression of a Buster Keaton.

After the group dissolved, Henry and Harfaux drew closer to the Surrealists. In 1933, they co-authored an article entitled 'On the subject of experiments related to the irrational knowledge of objects' ${ }^{41}$ In keeping with the concerns of the Surrealists, this interest in objects corresponds to the way in which the gags in burlesque cinema were constituted. The slapstick scenes were often played out in the same studios and the gags improvised based on what was available on the set, including stage props and scenery that reappeared in other productions. Such objects also played a determining role in the genesis of the gags, where they were often rediscovered through playing against type. They have, in any case, a central importance in the 'photo-gags' that Harfaux and Henry produced in 1935. The incongruous presence of a wig in the palm of a hand or a clothes peg clipped to a chin are images that draw the attention of the spectator. $^{42}$

An examination of the work of Harfaux highlights the various forms that humour can take in photography; from satire to irony, from nonsense to black humour, and even burlesque. Nevertheless, rather than a mobilisation of certain procedures, Harfaux seems to consider the use of humour as an existential stance. As Jacques Vaché had declared, 'Umour [sic] is too closely derived from feeling for it not to be very difficult to express - I think it is a feeling - I was almost going to say a SENSE - also - of the theatrical pointlessness (and joylessness) of everything'. ${ }^{43}$ Vaché had criticised the pretention of artists who succumbed to the temptation of making 'umoristique' works. For him, this confused an artist's priorities since humour stemmed more from a metaphysical attitude. Such conceptions help explain Harfaux's reluctance to promote his work. The 'sense of humour', if corresponding to an internal positioning, no doubt contributed to a relativism of personal ambition.

This study incites a reconsideration of the importance of laughter in the thinking of the members of Le Grand Jeu. We know the constant fascination that the enigma of comedy exerted on Henry, his attraction for a scathing humour capable of presenting the world as a 
cruel farce. Nonetheless, the attachment of the other collaborators in the review to the pataphysics of Alfred Jarry should not be neglected. For Gilbert-Lecomte and Daumal, humour was not a simple addition to their revolt but an integral feature. Hence, there is a real congruity between the bizarre or burlesque photomontages, and the gags portrayed by Harfaux, and the existential search of his friends. In a broader sense, Harfaux's output demands a reassessment of the role of humour in the work of photographers associated with the Surrealist movement, as well as its role in the thinking of Breton, Desnos and Soupault, especially given the numerous echoes between the images, the texts, the staging and the collages, and the important affinities of the movements, which were in such close contact without actually coming together.

\section{Translated by Richard K. Pinder}

\section{$\underline{\text { Captions }}$}

Figure 1. Artür Harfaux, Hommage au marquis de Sade, gelatin silver print, 1930. (C) Le Nyctalope.

Figure 2. Artür Harfaux, Moi et moi, Dédoublement, double exposed gelatin silver print, 1927. (C) Le Nyctalope.

Figure 3. Artür Harfaux, Untitled (Triple portrait, from left to right, of Roger GilbertLecomte, René Daumal, and Roger Vailland), collage of photographs repointed in gouache, ca. 1928. (C) Le Nyctalope.

Figure 4. Artür Harfaux, Scène de la vie courante, photomontage, 1929. (C) Le Nyctalope.

Figure 5. Artür Harfaux, Untitled, photomontage, 1928. (C) Le Nyctalope.

Figure 6. Artür Harfaux, Untitled, photomontage, 1927. (C) Le Nyctalope.

Figure 7. Artür Harfaux, Untitled, photomontage, 1929. (C) Le Nyctalope.

Figure 8. Artür Harfaux, Untitled, photomontage, 1930. (C) Le Nyctalope.

\footnotetext{
I am grateful to Madeleine Harfaux and Jean-Paul Neveu for permission to reproduce Artür Harfaux's photographs in this article.

1 - In a spirit of provocation, Arthur Harfaux germanised the spelling of his given name at the end of the First World War. He subsequently retained this spelling to sign his works.

2 - The first edition was dedicated to the 'Nécessité de la révolte' (June 1928), the second to Arthur Rimbaud (May 1929), and the third to 'L'Univers des mythes' (October 1930). These three editions and uncompleted works planned for the fourth have been republished in Le Grand Jeu, collection complète, Paris: Jean-Michel Place 1977.
} 
3 - Henri Béhar, 'Les grands jeux des surréalismes' in Olivier Penot-Lacassagne and Emmanuel Rubio, Le Grand Jeu en mouvement, Lausanne: L'Âge d'homme 2006, $29-42$.

4 - For photographs by René Maublanc, Alfred Schulze (Wols), and Luc Dietrich, see Sima, Paris: Musée d'art moderne de la ville de Paris 1992, 256 and 259.

5 - Two photographs - one of Daumal, the other of Gilbert-Lecomte - were used as models for paintings by Š́ma. See Nelly Feuerhahn and David Liot, Grand Jeu et surréalisme, Reims: Ludion-Musée des beaux-arts de la ville de Reims 2003, 174-75.

6 - This image should have featured in the special number, dedicated to Sade, of the Belgian review Le Rouge et le noir, but in the end was not published.

7 - Michel Random, Le Grand Jeu, les enfants de Rimbaud le Voyant, Paris: Le Grand Souffle 2003, 36.

8 - René Daumal to Roger Gilbert-Lecomte, 12-13 October 1927, in René Daumal, Correspondance I (19151928), Paris: Gallimard 1992, 197: 'Si tu voulais m'égorger [...], il me serait permis de ne pas résister'.

9 - See Patrick Roegiers, Magritte et la photographie, Paris: Ludion 2005.

10 - René Daumal, 'Nerval le nyctalope', Le Grand Jeu, 3 (October 1930), 20-31.

11 - Maurice Henry, interview with Raphaël Sorin, in Sima, 281: 'Si aujourd'hui je survis, sans amertume et sans regrets, c'est parce que, par la pensée, je suis près de Daumal' ('If today I survive, without bitterness and without regrets, it is because in my thoughts I am close to Daumal').

12 - Maurice Henry, 'Arthur Harfaux. Qui est-ce?', Phases, second series, 4 (December 1973), 85 : 'Ce qui l'a marqué, c'est le Grand Jeu. Mais il est encore étonné d'avoir été entraîné dans ce mouvement auquel il affirme qu'il n'a jamais adhéré totalement'.

13 - In 1930, Harfaux was employed by the Société de Contrôle et d'Expertise de tableaux. From 1936, he practiced many professions before becoming the director of the advertising department of the Nouvelles Galeries in 1951.

14 - René Daumal, 'Lettre ouverte à André Breton sur les rapports du surréalisme et du Grand Jeu', Le Grand Jeu, 3 (October 1930), 76.

15 - Roger Gilbert-Lecomte, 'Avant-propos', Le Grand Jeu, 1 (June 1928), 2 : 'nous marchons unis tous ensemble, chacun portant son propre cadavre sur son dos. [...] nous ne formons pas un groupe littéraire, mais une union d'hommes liés à la même recherche'.

16 - Clément Chéroux, 'La photographie par tous, non par un', in Quentin Bajac et al., La Subversion des images, Paris: Centre Pompidou 2009, 23: 'primauté du collectif sur l'individu'.

17 - Ibid., 24: 'la suprématie d'une création égocentrée'.

18 - This photomontage was published in La Révolution surréaliste, 12 (15 December 1929), 73.

19 - This first exhibition included Š́ma's paintings, Dida de Mayo and Henry's drawings, primitive sculptures and Harfaux's photographs. Henry, 'Artür Harfaux. Qui est-ce?', 84.

20 - Recent exhibitions include 'Artür Harfaux' at Galerie Zannettacci in 1985, and 'Artür Harfaux \& Maurice

Henry' at Musée des beaux-arts de Tourcoing in 2002. Some of Harfaux's photographs were also exhibited in 'Grand Jeu et surrealism' at Musée des beaux-arts de la ville de Reims in 2003-04, and in 'La subversion des images' at Centre Georges Pompidou in $2009-10$.

21 - For example, Hendrik Cramer produced dream stories. See 'Dans une coquille de moule', Le Grand Jeu, 1 (June 1928), 42-47.

22 - Le Grand Jeu, 2 (May 1929), 17.

23 - Maurice Henry, 'La nécessité de la révolte', Le Grand Jeu, 1 (June 1928), 9: 'cet épouvantail des collèges'.

24 - Dawn Ades, Photomontage, London: Thames \& Hudson 1989, $22-23$.

25 - See René Daumal and Artür Harfaux, Demain il sera trop tard, Amiens: Le Nyctalope 1985. This book includes Daumal's unpublished letter and Harfaux's drawings.

26 - Nelly Feuerhahn, Maurice Henry, la révolte, le rêve et le rire, Paris: Somogy - Éditions d'art 1997, 45:

'Alors! Toujours de l'enfant aux épinards!'

27 - André Breton, Anthologie de l'humour noir [1939], Paris: Jacques Pauvert 1966.

28 - Roger Gilbert-Lecomte, La Vie, l'amour, le vide et le vent, Paris: Les Cahiers libres 1933.

29 - René Daumal, 'La pataphysique et la révélation du rire', Bifur, 2 (1929), reprinted in René Daumal,

L'Évidence absurde, essais et notes I (1926-1934), Paris: Gallimard 1972, 19: '[ ...] je soutiens et je sais que la pataphysique n'est pas une simple plaisanterie. Et si à nous autres pataphysiciens le rire souvent secoue les membres, c'est le rire terrible devant cette évidence que chaque chose est précisément [...] telle qu'elle est et non autrement, que je suis sans être tout, que c'est grotesque et que toute existence définie est un scandale'. 30 - Ibid., 20: 'Le rire pataphysique, c'est la conscience vive d'une dualité absurde et qui crève les yeux; [...] il est la seule expression humaine de l'identité des contraires'. 
31 - Les Aventures des Pieds Nickelés and Bibi Fricotin are based on the illustrated stories of Louis Forton (1879-1934), which were published in 1908 and 1924 in L'Épatant. The first film begins with a close-up of the comic strip, from which the three heroes leap.

32 - Nelly Feuerhahn, 'Les gagmen associés: Maurice Baquet, actor of Maurice Henry and Arthur Harfaux', Cinémaction, 82 (1997), 138: 'the notes concerning their respective rights established a share based on 73.34\% for Maurice Henry and $26.66 \%$ for Arthur Harfaux'.

33 - Henry, 'Arthur Harfaux. Qui est-ce?', 86: 'Les inventions d'Arthur sont folles, délirantes, fragments de rêves que je passe au crible de mes connaissances cinématographiques pour les changer en réalités réalisables $[\ldots]$ '.

34 - Some of these photomontages appeared in Le Grand Jeu, 3 (October 1930), 55, while others should have appeared in the unrealised fourth issue of Le Grand Jeu.

35 - Roger Caillois, 'La mante religieuse', Minotaure, 7 (June 1935), 5.

36 - See Feuerhahn and Liot, Grand Jeu et surréalisme, 50-51.

37 - Rosalind Krauss, 'Corpus Delicti', October, 33 (Summer 1985), 31-72.

38 - See Le Grand Jeu, 1 (June 1928), 4 and 64; Le Grand Jeu, 3 (October 1930), 59; and Sima, 268.

39 - Petr Král, Le Burlesque ou Morale de la tarte à la crème, Paris: Stock 1984, 95-116.

40 - Michael Richardson, Surrealism and Cinema, Oxford: Berg 2006; and Alain and Odette Virmaux, Le Grand Jeu et le cinéma, Paris: Éditions Paris Expérimental 1996.

41 - Artür Harfaux and Maurice Henry, 'À propos de l'expérimentation portant sur la connaissance irrationnelle des objets', Le Surréalisme au service de la révolution, 6 (May 1933), 23-24.

42 - See Feuerhahn, Maurice Henry, 31 and 34.

43 - Jacques Vaché, 29 April 1917, in Jacques Vaché, Lettres de guerre, précédées de 4 essais d'André Breton, Paris: Éric Losfeld 1970, 45: 'l'Umour [sic] dérive trop d'une sensation pour ne pas être très difficilement exprimable - Je crois que c'est une sensation - J'allais presque dire un SENS - aussi - de l'inutilité théâtrale (et sans joie) de tout'. 